\title{
The Metsamor Nuclear Power Plant in the Active Tectonic Zone of Armenia is a Potential Caucasian Fukushima
}

\author{
Rauf Nadirov ${ }^{*}$, Ogtay Rzayev ${ }^{2}$ \\ ${ }^{1}$ Applied Geology and Geophysics Department, Azerbaijan National Academy of Sciences, Oil \& Gas Institute, Baku, Azerbaijan \\ ${ }^{2}$ Baku Higher Oil School, State Oil Company of Azerbaijan Republic, Baku, Azerbaijan \\ Email: *nadirs@ogi.az, oktay.rzayev@socar.az
}

How to cite this paper: Nadirov, R. and Rzayev, O. (2017) The Metsamor Nuclear Power Plant in the Active Tectonic Zone of Armenia is a Potential Caucasian Fukushima. Journal of Geoscience and Environment Protection, 5, 46-55.

https://doi.org/10.4236/gep.2017.54005

Received: February 17, 2017

Accepted: April 16, 2017

Published: April 19, 2017

Copyright $\odot 2017$ by authors and Scientific Research Publishing Inc. This work is licensed under the Creative Commons Attribution International License (CC BY 4.0).

http://creativecommons.org/licenses/by/4.0/

\begin{abstract}
This article describes complex geological structure of the region where Metsamor Nuclear Power Plant (MNPP) in Armenia is located. This region of the Lesser Caucasus is characterized by high volcanic activity, tectonic stresses, and movements along the edges of active, highly seismic tectonic blocks. Moreover, this station literally sits on the active tectonic fault of compression type. When construction of the plant commenced, seismic risks were significantly understated. This fact was confirmed by destructive Spitak earthquake with over 25 thousand death tolls. Analysis of intensitys of the earthquakes in the area of the MNPP, their focal mechanisms and risks of movements along active tectonic faults is given in the article. With reference to numerous papers of Armenian, Russian and European researchers regarding seismic hazards and risks in the area of the Nuclear Power Plant, the conclusion about the soonest shutdown and conservation of Metsamor Nuclear Power Plant has been made.
\end{abstract}

\section{Keywords}

Nuclear Disaster, Metsamor, Evaluation of Seismic Hazards, Tectonic Active Zone, Armenia

\section{Introduction}

The Metsamor Nuclear Power Plant (Armenian Nuclear Power Plant, ANPP) located in the city of Metsamor, west of Yerevan, Armenia's capital and not far from Turkish border (Figure 1), built in 1976 is a potential source of danger, with of risk of growing with time. This power plant has two WWER-440/230 type reactors, each with the gross output $408 \mathrm{MW}$. The nuclear plant is located 


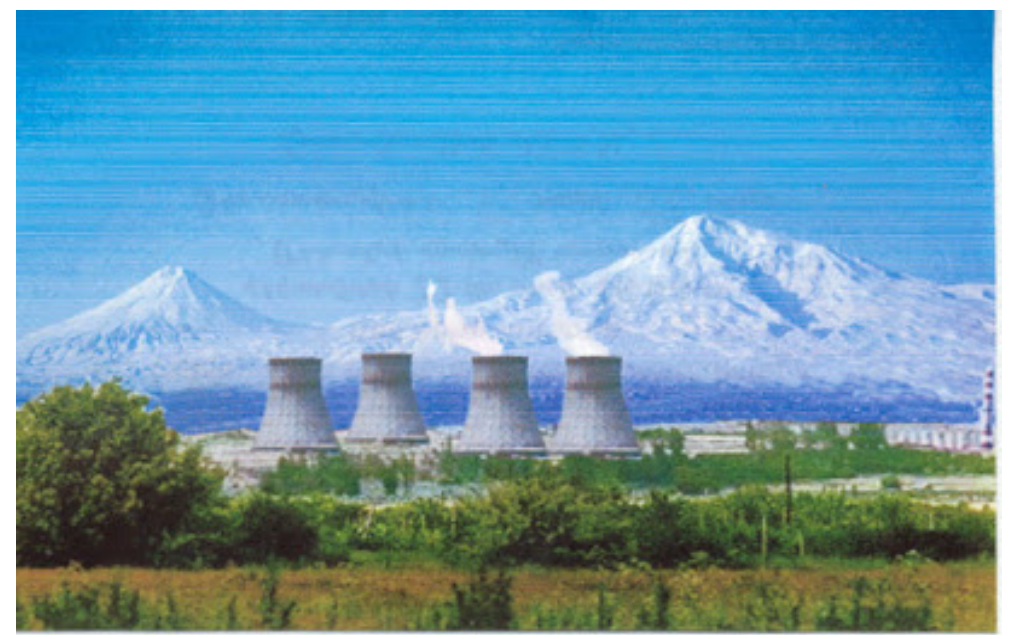

Figure 1. The metsamor nuclear power plant at turkish border.

$36 \mathrm{~km}$ away from Yerevan, $100 \mathrm{~km}$ from the Turkish city Kars, $30 \mathrm{~km}$ from Igdir (Turkey), and not very far from the borders of the Islamic Republic of Iran and Nakhchivan Autonomous Republic of Azerbaijan. The ANPP is the most unreliable active reactors in the world in use. During construction of the power plant, Soviet experts objected to the realization of the project expressing their concerns over its construction in the Ararat (Agridag) active seismic zone.

The epicentre of Spitak earthquake that occurred in 1988 in Armenia was at $75 \mathrm{~km}$ distance from Metsamor Nuclear Power Plant. After the earthquake, as part of the cautionary measures, the plant was shut down. However, in 1995, facing acute shortage of energy, Government of Armenia reopened the power plant despite the warnings of international experts. Despite millions of dollars allocated by the European states and the U.S. to ensure the plant met the up-todate safety standards, the plant had been assessed to be "oldest and least reliable" by the EU.

According to international and regional organizations, the operation of this nuclear power plant fails to meet the internationally accepted safety standards. Metsamor is an old station without any protective shield; it was built over solid basalt near the crystalline basement carrying no risk of deformation. According to expert estimations, service life of the plant was 30 years. Although this period ended in 2001, the plant is still in use, posing a threat to the regional safety.

\section{Geological Setting, Tectonic Blocks, Faults and Volcanism}

Geologically, an area where Metsamor NPP is formed by the layers of sedimentary deposits of Paleozoic-Triassic period and located within the Alpine structural bodies made up by the rocks of Cretaceous and Paleogene age. Upper Cretaceous ultrabasite intrusions were also found in this zone. The intrusions of different granitoid types have been attributed to pluton bearing the same name.

In terms of geological development, in Armenia, the Yerevan-Ordubad synclinorium had borne the character of geoanticline in Jurassic period, had intensively depressed during the Paleogene period before being exposed to intensive 
uplift in the Miocene period [1].

The intrusive magmatism of Armenia can be divided into two stages: during the upper Cretaceous ultra-major magma products poured into the intrusive rifts creating ultrabasite mass, and formed the granitoid intrusions during the Paleogene-Neogene period. All aforementioned could be clearly seen on the Map of the Deep Structure of the Caucasus according to the Space Data [2].

As seen from the map, the area of Metsamor where the Armenia Nuclear Power Plant is located is a seismically active territory. This territory is mainly made up by the complex of mountainous rocks formed as a result of metamorphosis of magmatic rocks in the upper layer of lithosphere (the Paleozoic Period) under the influence of various erosion factors in continental conditions.

It should be noted that Metsamor Nuclear Power Plant had been built despite objections of the Soviet experts regarding the choice of its site. The complex landscape of this area and presence of multiple intrusive faults confirm the high rate of tectonic activity of the area.

The thickness of the layer of sedimentary deposits in that area is small. The thickness of the layer of the Quaternary sedimentary deposits over the Paleozoic metamorphic foundation is very small. This, in turn, indicates to high risk of the earthquake occurrence, and high scale of subsequent destruction.

The site of the power plant is over the large intrusive faults, also, a geodynamic belt. As indicated by the space data map, this area as a network of different intrusive faults of closely located "microblocks", exposed to the fracturing due to the pressure from tectonic blocks had been deformed and remains a zone of high seismic activity. The low thickness of the deposits once more indicates to the presence of orogenic regime and erosion in the region, very active erosion, closeness of the metamorphic foundation to the surface, while the location of blocks in the area subject to pressures denotes the high geodynamic activity at this territory [2].

The studies point out that as indicated by the comparative analysis of the geological structures of Caucasus, Lesser Caucasus and the Anatolia plateau, these regions resemble one another in terms of their tectonic conditions and volcanic activity.

According to some assumptions, in the geological structuring of Lesser Caucasus and Armenia, the collision with the Eurasian continent located farther to the south plays an important role. As a result of that, along the transform faults (northern Anatolia, Eastern Anatolia), different microplates sliding past one another relatively fast and stripes have emerged. Then, the pressing and pulling segments had emerged; subduction, sliding had occurred, and from the edges of the bordering massifs, snaps (in the form of spanning massifs) had come about [3].

Menderes, Artvin-Bolnisi, Alagoz-Julfa tectonic units, which are presumably parts of the greater Central Iran tectonic unit, played an important role in geological formation of the region. During the Oligocene-Miocene period, the Central Iran massif had been divided into separate uplifts and troughs creating Mid- 
dle Aras depression zone [4].

The North Anatolian fault stretching to Erzurum is divided into two branches: one of them stretches past the Kars volcanic plateau, extending to Armenia, while the other one rises in the upstream of the Aras River. The last branch is divided into Arazyani and Nakhchivan faults confining the Middle Aras depression zone. These faults are connected with the North Anatolia fault and active as a part of a transform fault and resemble each other in many aspects, in terms of geological features.

The aforementioned faults along with others indicate that the structure of the region (Yerevan and Nakhchivan) is made up by blocks and had caused the formation of large numbers of horst-anticlinal and graben-synclinal tectonic elements, and accumulation of Oligocene-Quaternary sedimentary deposits. Located perpendicular to the Aras River, the "island" uplifts (Aghridagh, Daridagh, Aghgaya etc.) were divided into small lowlands [5].

The study of the internal structure of this zone using the space data and the tectonic-physical analysis of wrinkles over there indicates that as a result of large-small several plates and their parts sliding past one another, a lowland along the fault had emerged and developed.

The first impulse to formation of this paleogeographic basin had been given by the activation of rift processes in the Aden and Red Seas, triggered by the sliding of the Arabian plate. The dependence of the region on the motion of small plates squeezed in between the Arabic and Eurasian plates and their parts has increased. As a result of relatively active, strong pressure of smaller plates and their parts against one another, pulling and other deformation movements, intrusive faults had emerged. The sliding deformation caused by the movement of the Central Iran massive further complicated the tectonic structure of the region, exaggerating its geotectonic activity.

Intensive ground volcanic processes took place till the anthropogenic period. Lava layers had covered not only east of Anatolia, but also central and southern parts of Lesser Caucasus and Iran.

The Lesser Caucasus system including Bazum, Pambak-Sevan, Zangazur, Vardenis, and Geghama mountain ranges surround most of the country located in the Transcaucasian volcanic plateau. There is a lowland between the Geghama and Sevan mountains. Aragats (originally Alagyoz) is the largest volcanic massif in South Caucasus. Its highest point is the Northern Summit (4090 m high). Additionally, there are summits of Kaputjugh (3904 m), Vardenis $(3522 \mathrm{~m})$ and Ajdaak (3597 m). In the north-west of Armenia lays Shirak plain, while in the south-west there is the Ararat plain. An average altitude of the area is $900 \mathrm{~m}$. Over $90 \%$ of Armenia is located over the altitude of $1000 \mathrm{~m}$. An average height is $1800 \mathrm{~m}$. The areas with the lowest altitude are located in the basin of Debed and Aras Rivers $(380 \mathrm{~m})$. The size of the lowlands is small. Most of the settlements in the basin of the Vorotan, Vokhchi, and Aras Rivers are located in the areas with the slope of 30 degrees, which hampers the organization and development of urban transportation. Geologically, Armenia is located in Lesser Caucasus and in 
the area of collision, obduction and accretion of multiple micro-plates, island arcs and active margins, and between Black sea and Caspian relicts of the Tethys paleo-oceanic systems.

Figure 2 and Figure 3 show that Metsamor NPP is obviously located in highly active compression fault zone.

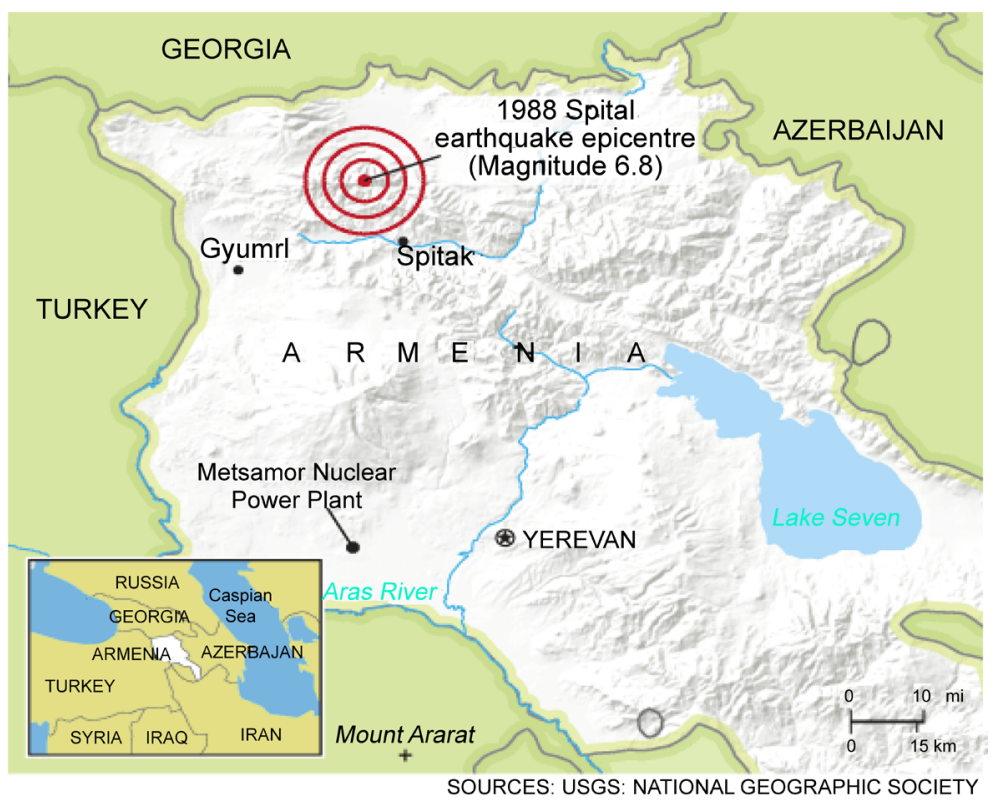

Figure 2. Map with location of the Metsamor Nuclear Power plant and Spitak earthquake epicentre in Armenia.

(a)

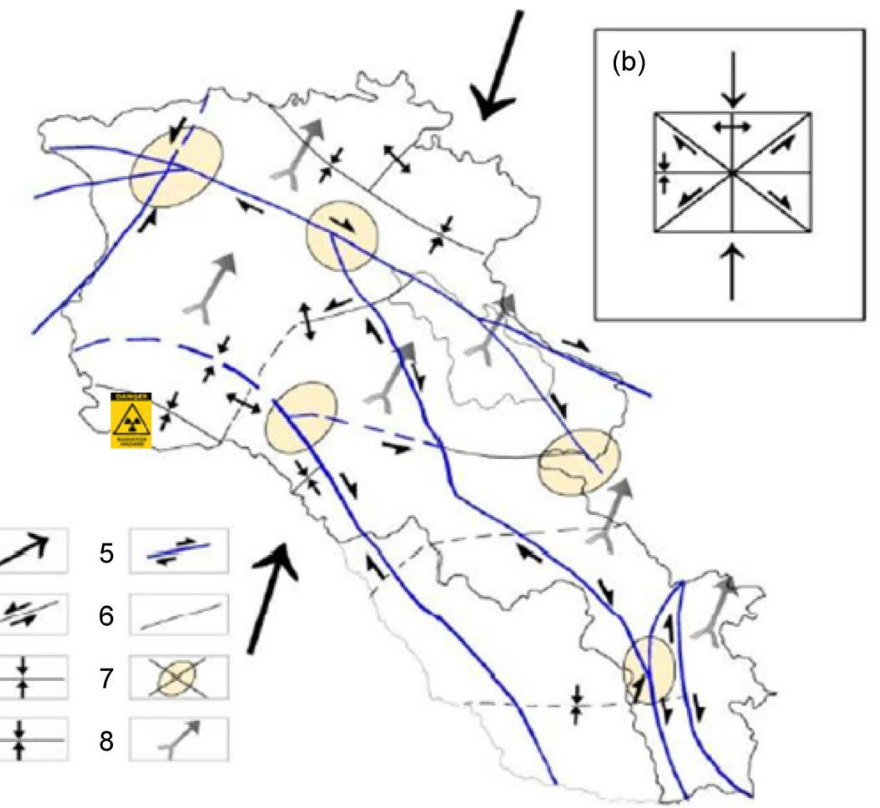

Figure 3. Elements of block structure of the Earth Crust on the territory of Armenia and potential active tectonic elements (a); and simple scheme of potential compressional faults' motions (b) [6]. Legend: 1-motions based on GPS data, 2-motions along the faults, 3-compression zones, 4-extension zones, 5-high activity faults, 6-low activity faults, 7-active fault intersection zones, motion of blocks according to GPS data. 


\section{Earthquakes and Seismic Hazard and Risk}

Armenia borders with Georgia, Azerbaijan, Turkey and Iran, and such factors as its landlocked position and absence of border with Russia affect its economic development. The transportation links with Russia are realized through highways. The railway links through Abkhazia and Azerbaijan were disrupted due to the conflicts blocking access to these areas. Consequently, Armenia has to rely on the Georgian port Poti for the imports and exports and on the transport communication lines with Iran. The country is located in low-lands with a complex landscape in the north-west of Armenian Highlands. There are mountains, plateaus, flatlands, river valleys and lowlands around the lakes in this area. The whole country is within the seismic zone with 7 - 11 intensity according to MSK scale (Medvedev-Sponheuer-Karnik scale similar to Modified Mercalli scale). In Armenia, in $20^{\text {th }}$ century devastating earthquakes occurred in 1926, 1931 and 1988 (Spitak earthquake).

Armenian specialists also do not deny potential hazard of a nuclear catastrophe in the near future. After Spitak earthquake average level of earthquake intensity, registered by the Armenian seismic stations network, increased. As A. E. Kazaryan indicated [7] "after Spitak earthquake average level of earthquake intensity, registered by the Armenian seismic stations network, increased" in the area.

In most cases earthquakes in the region are intra-crustal, with the average focal depth 4 to $15 \mathrm{~km}$ from the surface. Statistical characteristics of seismicity of the investigated region were obtained based on processing of the master catalogue of earthquakes provided by the National Seismic Service (NSS) of the Republic of Armenia, and are shown below as histograms in Figure 4 [7].

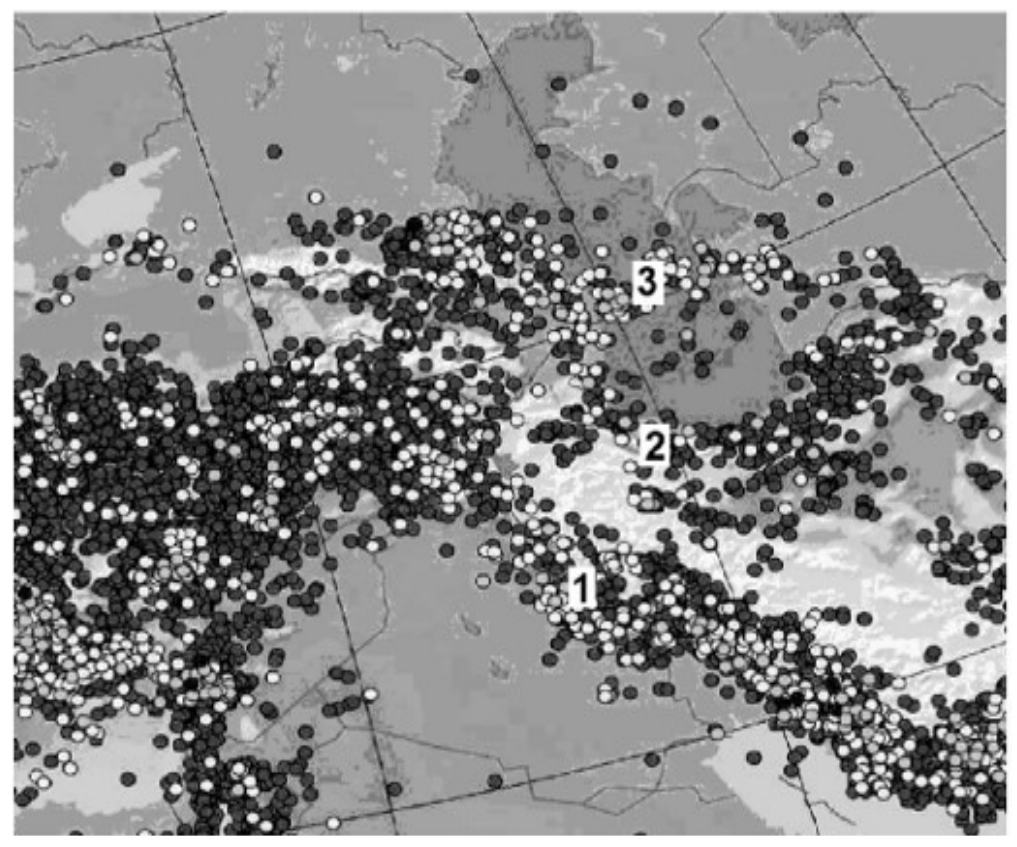

Figure 4. Schematic map of the territorial distribution of earthquakes at the territory of South Caucasus and in adjacent areas. 
The most powerful earthquakes in vicinity of the Metsamor Nuclear Power Plant have Power Class between 7 and 10-see Figure 5 [8].

The Armenian Nuclear Power Plant over a long and deep tectonic fault poses a great danger. Besides its technogenic factors, the Metsamor plant together with its geological position presents danger to the region. As mentioned above, both Turkey and Armenia are located in the active seismic zones. The fact that deep tectonic fault crosses the territory where Armenian nuclear power plant is located increases the likelihood of the occurrence of the tectonic developments, including earthquakes. This is related to the abovementioned tectonic faults crossing the territory. Earthquakes recur in the tectonic fault zones regularly. Therefore, a high risk of the occurrence of a natural disaster in the area of the location of the plant exists.

Also it is clearly seen from the map prepared (Figure 6) by the National Service of Seismic Defence of the Ministry of Emergency situations, the Metsamor NPP is located over the deep fault and the area with the history of earthquakes with $\mathrm{Mw} \geq 7.0$ [9].

A group of prominent Russian scientists from Institute of the Earth's Physics of the Russian Academy of Sciences, including such famous researchers as academicians A.V. Nikolayev and V.I. Ulomov, professors V.V. Steinberg and E.A. Rogozhin were invited by the Government of Armenia in 1992 to analyze all available seismological, geological, geophysical, seismic-tectonic and soil mechanics data for the site of Nuclear Power Plant to make an authoritative decision about further fate of the Metsamor NPP. Here are a few citations from the "Expert Evaluation of Seismic Hazard for the Site of Armenian Nuclear Power Plant" dated 12.05.1992 [10]:

- Most dangerous for the site of Atomic Power Plant (APP) is a tectonic cross-point close to it $(0.5 \mathrm{~km})$, on the intersection of sub-meridional Ara

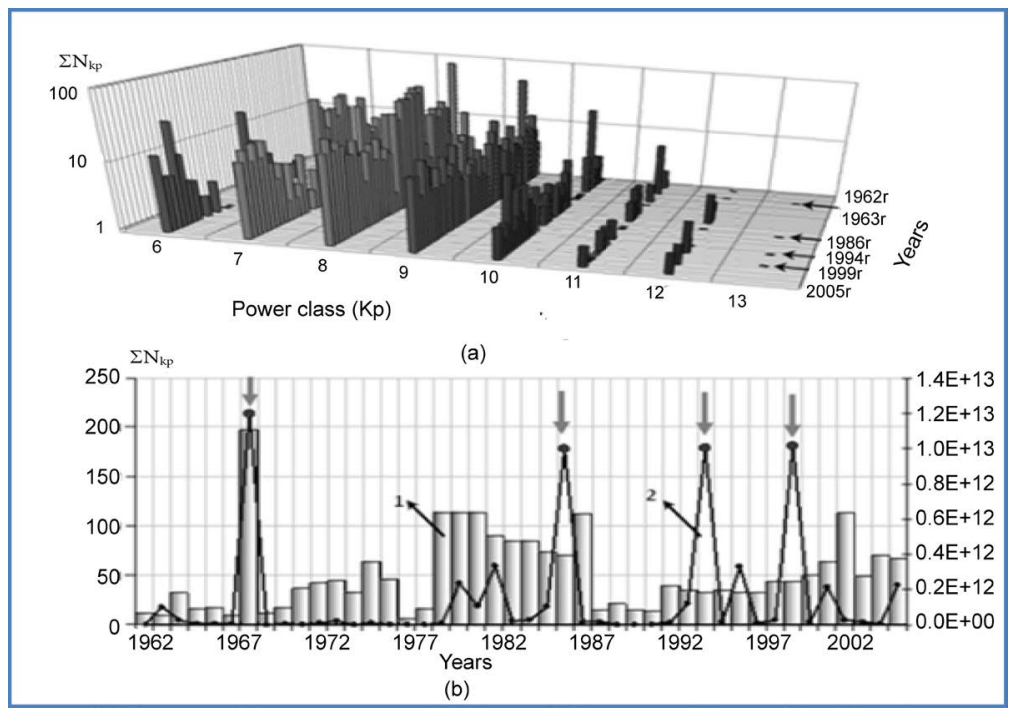

Figure 5. [8]. (a) 3D graph-quantitative breakdown of earthquakes during the period of 1962-2005 on the territory of the south-eastern part of the Lesser Caucasus by the years and energy classes; (b) Distribution of seismic events (1) and total released energy (2). 


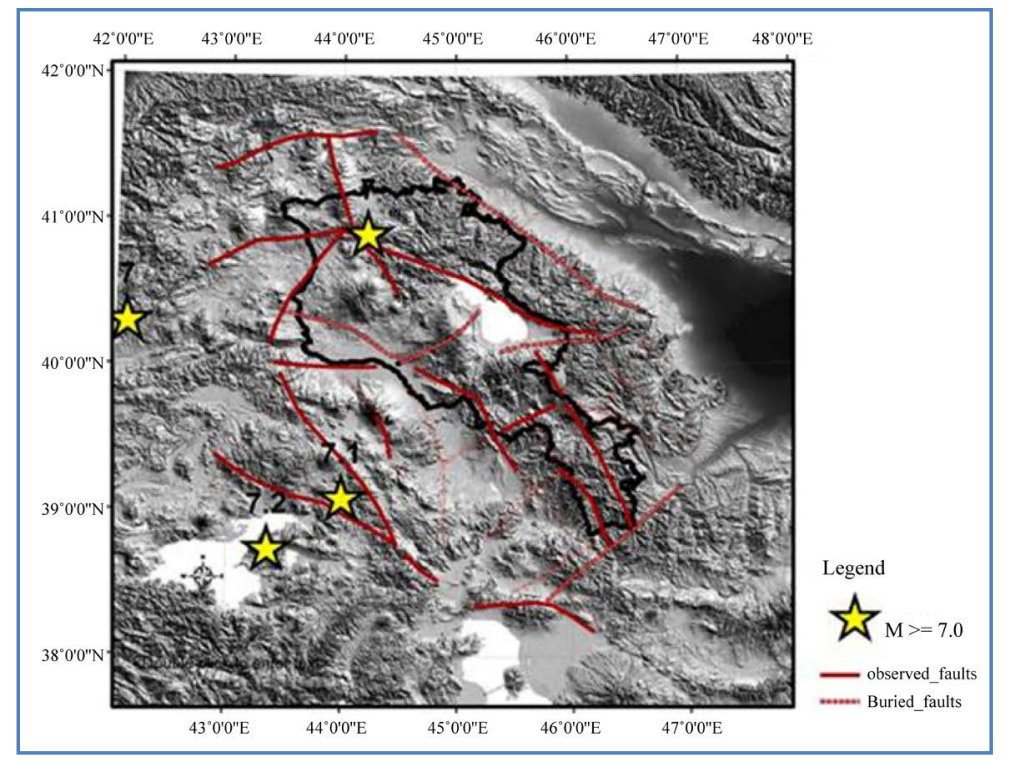

Figure 6. Map of Deep Faults and Powerful Earthquakes $M w \geq 7.0$ [9].

gats-Spitak tectonic fault with South-Yerevan fault, having high seismic potential $(M>6)$. In one of tectonic cross-points of this fault, less than $50 \mathrm{~km}$ to the east from APP, in 851-893 years, series of destructive Dvin earthquakes took place, with intensity at least 9 and huge fatalities.

- Thus, most realistic evaluation of the potential earthquake intensity for the site of Armenian APP should be 8, maximum calculated earthquake intensity 9 . In the area of maxima of spectral-response characteristics of bedded formation oscillations incremental intensity may reach $1 \mathrm{M}$.

- At a distance minimum 0 - $5 \mathrm{~km}$ of this potential earthquake origin from the site of Armenian APS, with the occurrence depth about $10 \mathrm{~km}$ and accounting for the specific character of macro-seismic field, seismic effect at the site is 9, whilst for maximum estimated intensity (MEM), even if we take Mmax $=7$, will exceed this value significantly and earthquake intensity and will be 9 .

- Concluding, it should be noted that in recent decades we observe increased seismic activity of the whole Armenian highlands, Caucasus and neighbour regions, induced by the seismic-geodynamic processes in Iran-CaucasusAnatolian region (detailed note of the expert group is enclosed) [10].

Member of this expert group, academician V.I. Ulomov in 2004 in his another expert conclusion concerning safe use of the Bilibin nuclear power station in Russia, did not hesitate to mention the Metsamor NPP in Armenia again [11] and wrote "It was decided that Armenian NPP must be abandoned because it is located in very seismologically dangerous area of Armenia", Figure 7 [11].

According to the Peer review of the European Nuclear Safety Regulators Group (ENSREG), the Peer Review Team further suggests to complement the 2011 PSHA by (i) with a review of the maximum intensity Mmax values which are regarded to be underestimated when compared to other recent seismic hazard assessments, and (ii) detailed investigations of the active faults close to the site using integrated paleoseismological techniques [12]. 


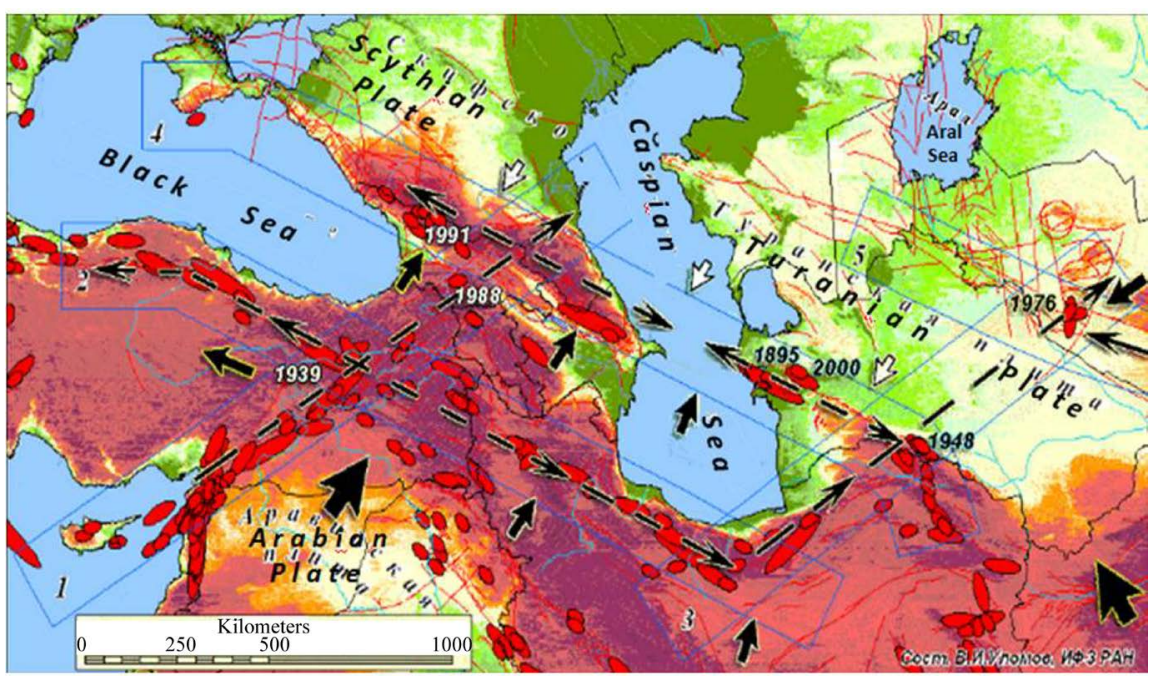

Figure 7. Map of the contemporary tectonic activity and stress concentration zones. From V. I. Ulomov's Expert Conclusion of Safe Usage of the Bilibin NPP [11].

\section{Conclusions}

Overall, the major natural and technogenic factors bolstering the threat of the Metsamor power plant for the regional states can be reduced to following conclusion. Although the plant during the construction had been designed to withstand up to an 8-intensity earthquake, it is located in the region that can potentially experience an 11-intensity earthquake according to the MSK scale.

Any delay of this safe and wise decision to abandon the Metsamor nuclear power plant will be resulted in a big catastrophe for all regions that could be called as the Caucasian Fukushima.

\section{References}

[1] Azizbekov, Sh.A. (1961) Geology of Nakhchivan ASSR. State Geological Mechanical Publishing House, Moscow. (In Russian)

[2] (1989) Map of the Deep Structure of the Caucasus According to the Cosmic Data. Ministry of Geology of the USSR, based on satellite images of structural lineaments. M1:1000000. (In Russian)

[3] Trifanov, V.G. (1983) Late Quaternary Tectogenesis. Nauka, Moscow. (In Russian)

[4] Echle, W. (1974) Zur mineralogic und petrogenesis jungteriarer tuffitischer Sedimentsim Neogen Becken nordlich Mihalicck Westanatolien Turkey. Neues Jahrbuch für Mineralogie-Abhandlungen, 12.

[5] Rzayev, O.A (2015) The Intrusive Structure of Nakhchivan Lowland and Its Tectonic Features. SOCAR Publishing House, Baku. (In Azerbaijani)

[6] Shakhbekyan, T. (2015) The Block Structure of the Crust of the Territory of Armenia and Its Role in Seismicity. Proceedings of Scientific Articles of Yerevan State University (YSU) Dedicated to the 95th Anniversary of YSU, Yerevan, Armenia, 110-119. (In Russian)

[7] Kazaryan, A.E. (2011) Analysis of Seismic-Dynamic Status of the Territory of Armenia as One of the Factors for the Evaluation of Current Seismic Hazard. Izvestiya of the Russian Academy of Sciences, Earth Sciences, 64, 29-42. (In Russian) http://earth.asj-oa.am/1997/1/29.pdf 
[8] Ovsepian, N.V. and Mkrtchian, G.A. (2014) Time-Power Distribution of Areal Seismicity of South-East Part of the Lesser Caucasus. Proceedings of All-Russian geological conference on Geology, Geo-ecology and Resource Potential of Urals and adjacent areas, Ufa, Russia, 77-83. (In Russian) http://ig.ufaras.ru/File/2Yconf2014/Ufa-conf_2014.pdf

[9] National Service of Seismic Defence of the Ministry of Emergency Situations Has Analyzed Results of the Earthquake in Turkey Happen on 23rd October 2011. Armenian News. Society 01.11.2011. (In Russian)

https://news.am/rus/news/80290.html

[10] Expert Evaluation of Seismic Hazard for the Site of Armenian Nuclear Power Plant (21.02.1992). (In Russian) http://seismos-u.ifz.ru/personal/bilibino.htm

[11] Ulomov, V.I. (2002) Nuclear Power Plants-Seismic Hazards. Expert Conclusion of Safe Usage of the Bilibin, 2004, NPP. (In Russian)

http://seismos-u.ifz.ru/personal/documents/Armenian_Nuclear_Power_Plant_Exa mination.pdf

[12] Nuclear Safety Regulators Group, ENSREG (2016) EU Peer Review Report of the Armenia Stress Tests. European.

http://www.ensreg.eu/sites/default/files/attachments/2016-07-20_4259241_armenia stress_tests_report-_ensreg_template_final.pdf

\section{Scientific Research Publishing}

\section{Submit or recommend next manuscript to SCIRP and we will provide best} service for you:

Accepting pre-submission inquiries through Email, Facebook, LinkedIn, Twitter, etc. A wide selection of journals (inclusive of 9 subjects, more than 200 journals)

Providing 24-hour high-quality service

User-friendly online submission system

Fair and swift peer-review system

Efficient typesetting and proofreading procedure

Display of the result of downloads and visits, as well as the number of cited articles

Maximum dissemination of your research work

Submit your manuscript at: http://papersubmission.scirp.org/

Or contact gep@scirp.org 